\title{
SENI MELAWAN PEDAGANG ASONGAN DI KERETA API LOKAL EKONOMI MERAK-RANGKAS BITUNG BANTEN
}

\author{
Musahwi, Minnati Zulfa Anika, Pitriyani \\ Pendidikan Sosiologi, Fakultas Keguruan dan Ilmu Pendidikan, \\ Universitas Sultan Ageng Tirtayasa \\ musahwi@untirta.ac.id
}

\begin{abstract}
This study attempts to uncover the resistance of hawkers against the prohibition of selling at stations and trains by taking the locus of Merak-Rangkasbitunglocal train. Specifically the purpose of this study is to uncover the daily hidden resistance that is concealed by hawkers. This kind of resistance model refers to Scott's concept from his theory which is the domination of the art of resistance or noted by the weapon of the weak againts of the elite or the policies which opressed them. In this study, used the qualitative-phenomenology methods. This approach is chosen to reveal the phenomena based on the perspectives of those who experience them directly, with an in-depth expression of the phenomenon of consciousness within them during resistance. The results of this study include: a) disobedience (keepselling) against the law by pretending not to know. b) sellingpretend as passengers. c) negotiating "as if" with the officer, meaning they end up violating, and d) resisting the ban on selling by rebel. The daily, unorganized and invidual resistance to this is done because there is no alternative to the economic solution for them; they have no capital; social, educational, and political. They are weak people, and according to them are increasingly weakened by the policy of the ban.
\end{abstract}

Keywords: cascading, ban, covert resistance 


\begin{abstract}
Abstrak
Studi ini berusaha untuk mengungkap perlawanan terselubung pedagang asongan terhadap larangan berjualan di stasiun dan kereta dengan mengambil lokus KA lokal ekonomi MerakRangkasbitung. Secara khusus tujuan studi ini adalah mengungkap perlawanan sehari-hari yang sifatnya tersembunyi pedagang asongan. Model perlawanan seperti ini mengacu pada konsep teori Scott tentang seni melawan yang dilakukan orang-orang lemah, atau lebih dikenal dengan senjatanya orang-orang kalah dalam melawan elit atau kebijakan yang dirasakan menindas mereka. Metode yang digunakan dalam studi ini adalah kualitatif-fenomenologi. Pendekatan ini dipilih untuk mengungkap peristiwa atau kejadian berdasarkan perspektif orang-orang yang mengalami langsung, dengan mengungkap secara mendalam fenomena kesadaran yang ada dalam diri mereka saat melakukan perlawanan. Adapun hasil studi ini antara lain: a) pembangkangan (tetap berjualan) terhadap hukum dengan cara berpura-pura tidak tahu. b) berjualan dengan menyamar sebagai penumpang. c) negosiasi "seolah-olah" dengan petugas, artinya mereka akhirnya tetap melanggar, dan d) melawan pelarangan berjualan dengan berjualan (sikap membandel). Perlawanan sehari-hari, tidak teroganisir dan invidual ini dilakukan penyebabnya adalah karena tidak ada altenatif solusi secara ekonomi bagi mereka, mereka tidak memiliki modal; sosial, pendidikan, maupun politik. Mereka orangorang lemah, dan menurut mereka semakin dilemahkan oleh kebijakan pelarangan tersebut.
\end{abstract}

Kata Kunci: pedagang asongan, larangan, perlawanan terselubung

\section{PENDAHULUAN}

Perlawanan adalah salah satu bentuk perjuangan dari tindak kekuasaan dan politik, sebagaimana Mills (1956) mengatakan bahwa, semua usaha untuk mendapatkan kekuasaan dan bentuk paling akhir dari kekuasaan adalah kekerasan. Perlawanan dapat diartikan juga sebagai salah satu sifat untuk menyangkal atau menolak adanya suatu kekuasaan yang berkembang dalam bidang sosial, ekonomi, maupun politik.

Sebagaimana studi tentang perlawanan sejauh ini, ia lebih banyak datang dari kalangan yang merasa ada ketidakadilan oleh kebijakan pemerintah. Dalam penelitian Siscawati (2014) tentang perlawanan masyarakat adat di Indonesia terhadap penguasaan hutan oleh negara, memberi penekanan bahwa, masyarakat adat merasa negara telah mengambil hak adat untuk memanfaatkan dan memelihara hutan yang ada di lingkungan mereka sendiri. Diketahui sejak era Orde Baru, pengelolaan dan pemanfaatan hutan diserahkan kepada masayarakat adat, mereka memiliki hak. Pada masa Reformasi, diambil alih oleh negara. Bagi masyarakat adat, regulasi ini merampas hak meraka. Namun, bentuk perlawanan masyarakat adat masih melalui jalur konstitusional. Mereka membentuk Alienasi Masyarakat Adat Nusantara (AMAN) dan memperjuangkan hakhak masyarakat adat melalui Mahkamah Konstitusi (MK).

Sementara Fringka (2016), masih tentang perlawanan masyarakat adat namun pada objek perlawanan yang berbeda, yakni tentang perlawanan 
masyarakat adat terhadap rencana penambangan bukit Batubasi di Sumatera Barat. Kebijakan pemerintah memberi izin terhadap rencana penambangan bagi masyarakat adat merugikan lingkungan yang mereka tinggali, terlebih tidak melibatkan masyarakat adat dalam pengambilan keputusan, yang diketahui baik buruknya lingkungan penambangan pada akhirnya yang merasakan pertama kali adalah masyarakat adat. Ada beberapa jalur perlawanan yang dilakukan masyarakat adat, di antaranya: mengajukan surat penolakan kepada perusahaan atas nama masyarakat adat, penggalangan tanda tangan sebagai simbol ligitimasi, pemasangan banner tentang penolakan, pemblokiran jalan hingga pengusiran. Dan yang terkahir adalah jalan diplomasi.

Karnaji(2005)tertarik padaperlawanan yang dilakukan oleh kalangan marginal ex pedagang kaki lima di Taman Surya Surabaya. Pemerintah kota Surabaya membuat kebijakan yang tidak populer bagi pedagang kaki lima, terutama yang selama ini membuka dagangan di sekitar Taman Surya. Pemerintah ingin memoles taman supaya indah dan tidak dikotori oleh para pedagang yang dianggapnya tidak teratur. Pada mulanya perlawanan bersifat akomodatif, dalam arti, para ex pedagang kaki lima melakukan aksi bersama-bersama mengadukan permasalahan mereka ke DPRD Surabaya. Namun jalur ini rupanya tidak memuaskan. Mereka membentuk suatu organisasi non pemerintah di internal mereka agar mereka lebih kuat. Di sisi lain, mereka merubah perlawanan dari cara-cara yang akomodatif ke bentukbentuk perlawanan yang brutal dan keras terhadap aparatus di sekitar Taman Surya, Surabaya.
Sementara Malik dan Prasetya (2014) secara khusus mengkaji tentang perlawanan pedagang asongan terhadap PT. Kereta Api Madiun. Perlawanan bermula ketika keluar kebijakan Menteri Perhubungan UU. No:73/2008 tentang perkeretaapian yang antara lain isinya adalah melarang pedagang asongan berjualan di stasiun. Peraturan tersebut tentu memutus akses ekonomi mereka. Aksi perlawanan yang mereka lakukan terhadap PT. Kereta Api adalah aksi dan semakin mengintensifkan berjualan di stasiun dan kereta. Perlawanan ini terusmenerus dilakukan, dan mendapatkan hasil yang tidak merugikan mereka. PT. KA Madiun memberi dua solusi: yakni pertama, merekrut mereka sebagai petugas kebersihan dan petugas parkir stasiun. Dan kedua, memberi pesangon bagi mereka yang tidak direkrut.

Studi-studi di atas memberi inspirasi untuk mengkaji tentang bentuk dan pola perlawanan yang semakin berkembang dinamis dalam kajian ilmu sosial. Sejauh ini, studi tentang perlawanan masih dominan pada bentuk perlawanan yang terbuka, adu kekuatan dan adu legitimasi. Dalam dinamika perlawanan terbaru justru yang perlu diperdalam pada masyarakat saat ini adalah, aksi-aksi yang tersembunyi dan tidak terkoordinir (individual). Dengan kata lain, adalah pembangkangan diam-diam terhadap elit maupun produk-produk hukum pemerintah yang dirasa menindas.

Untuk menjawab kegelisahan akademiktersebut,studiiniberusahauntuk mengungkap bentuk dan pola perlawanan terselubung terhadap kebijakan yang dirasa menindas, dengan mengambil lokus perlawanan pedagang asongan di KA lokal ekonomi Merak-Rangkasbitung. 
Penelitian ini tentu berbeda dengan studi yang dilakukan oleh Malik dan Prasetya (2014) yang lebih fokus pada perlawanan terbuka pedagang asongan terhadap PT. KAI. Tujuan dari penelitian ini adalah mengungkap perlawanan sehari-hari yang sifatnya tersembunyi dari para pedagang asongan. Model perlawanan seperti ini mengacu pada konsep teori Scott tentang seni melawan yang dilakukan orangorang lemah, atau lebih dikenal dengan senjatanya orang-orang kalah.

\section{LANDASAN BERPIKIR}

Perlawanan sehari-hari adalah suatu kajian mikro; yakni bagaimana subjek yang melakukan perlawanan, tidak pernah merencanakan, namun perasaan bahwa diri mereka disubordinasi oleh kebijakan yang memberi kesan elitis selalu ada dalam bayangan dan pikiran mereka. Sampai dengan saat ini, James Scott adalah tokoh yang paling berpengaruh melalui karyanya Senjatanya Orang-orang Yang Kalah (2000); Moral Ekonomi Petani, (1994); Perlawanan Kaum Tani (1993).

Bagi Scott, perlawanan dari kelas yang lebih rendah adalah (semua) tindakan oleh (para) kelas itu dengan maksud untuk melunakkan atau menolak tuntutan-tuntutan (misalnya: sewa, pajak, penghormatan) dalam arti kebijkan yang dikenakan pada kelas itu oleh kelas di atasnya untuk mengadukan tuntutannya sendiri terhadap kelas tersebut, perlawanan dapat dimaknai sebagai suatu tindakan kontradiktif yang ditujukan untuk mencapai suatu tujuan. Lebih jauh, James Scott menuturkan bahwa kelompok subaltern (marginal/tidak memiliki akses) selalu memiliki ketergantungan dengan perekonomian yang membuat mereka harus memiliki subsistensi dan norma resiprositas dalam setiap langkah yang diambil dalam hidupnya, para kelompok subaltern tereksploitasi dengan apa yang ada "diatas" mereka, namun mereka hidup bukan karena keterpasrahan dan keputusasaan, melainkan mereka melawan dengan senjata-senjata yang lebih kecil namun lebih banyak hasil yang mereka dapat.

Tujuan yang sesungguhnya dari perlawanan ialahuntuk memperkecilatau menolak sama sekali klaim-klaim kelas dominan terhadap mereka. Kesadaran kolektif yang dimiliki membentuk suatu gerakan perlawanan yang memunculkan suatu tuntutan-tuntutan.

Scott (1993) membagi dua sifat perlawanan, yaitu perlawanan terbuka dan tertutup: 1). perlawanan terbuka bersifat terorganisir, tersistematis dan kooperatif, berprinsip, memiliki akibat revolusioner, dan mengandung gagasan yang meniadakan dominasi itu sendiri; 2). perlawanan tertutup bersifat tidak terorganisasi, tidak sistematis dan individual, bersifat untung-untung atau 'pamrih', tidak mempunyai akibat revolusioner dan dalam maksud dan logikanya mengandung arti penyesuaian dengan sistem dominasi yang ada.

Sebagai landasan berpikir penelitian ini digunakan sifat perlawanan yang kedua. Dalam pandangan Scott (2000: 38-65) kaum lemah yang tertindas, mereka yang tidak punya akses terhadap ekonomi dan politik, memaknai atau mengartikulasikan sifat perlawanan dan protes sosial ke dalam rutinitas kehidupan sosial mereka. Melawan bisa tanpa waktu dan tanpa tempat. Karena itu berbeda dengan model gerakan-gerakan sosial kontemporer, model ini bersifat tradisional dan tidak memerlukan 
manajemen gerakan yang sistematis dan terorganisir, tidak memerlukan basis massa, tidak perlu pemimpin, dan ideologi tertentu, kecuali pemahaman bahwa mereka hidup dalam ketertindasan kaum elit. Bentuk perlawanan yang biasa ditemukan adalah sembunyi-sembunyi. Mimiliki konotasi pembangkangan oleh orang-orang yang dilemahkan atau disingkirkan sedemikian rupa untuk kepentingan yang tidak memihak dan menguntungkannya.Kelompoksubaltern ini melawan karena keadaannya yang diperburuk bukan karena sebab takdir yang diberikan Tuhan, melainkan sebab tersebut diperburuk oleh sistem-sistem yang menghimpitnya seperti aparatus dari tingkat desa hingga pusat yang sebenarnya mengetahui begitu buruknya keadaan masyarakat miskin. Misalnya pada petani miskin atau lebih dikenal petani gurem. Meski begitu, mereka tetap menindas dengan cara mewajibkan adanya upeti, pajak tanah, dan uang sewa ditujukan kepada para petani yang kondisinya saja tidak dapat lepas dari pertanian dan wabah musiman.

Dengan demikian, pemahaman dan konsep teori Scott tentang perlawanan sehari-hari yang bersifat tersembunyi ini menjadi acuan memahami model dan bentuk perlawanan yang dilakukan pedagang asongan di kereta api lokal ekonomi Merak-Rangkasbitung.

\section{METODOLOGI PENELITIAN}

Untuk memotret fenomena perlawanan tersembunyi pedagang asongan di kereta api lokal ekonomi Merak-Rangkasbitung, maka digunakanlah jenis penelitian kualitatif. Fenomena yang dikaji oleh metode kualitatif ini diarahkan pada pemeriksaan terperinci terhadap persoalan yang muncul secara alamiah dalam kehidupan sosial (Neuman, 2013: 189). Konteks perlawanan sehari-hari dapat dikatakan sebagai kondisi setting sosial yang alami. Melawan tanpa perencanaan dan tanpa waktu adalah suatu fenomena yang khas, akan berbeda di tempat lain, meskipun penelitian ini tidak bertujuan membedakan atau menjeneralisasi ke tempat lain. Di samping itu juga penelitian ini tidak bertujuan memberi prediksi keadaan dan fenomena di masa yang akan datang, kecuali hanya ingin menggambarkan kondisi apa adanya berdasarkan apa yang dikatakan orangorang, dari bagaimana orang-orang bertindak, dan simbol-simbol tertentu yang dipergunakan oleh orang-orang, dalam hal ini subjek penelitian.

Sementara pendekatan yang digunakan adalah fenomenologi. Fenomenologi, berusaha mengungkap realitas sebagaimana adanya. Lebih jauh, fenomenologi berusaha mengungkap yang paling dalam dari kesadaran pelaku tentang perlawanan dan segala bentuk negasi lainnya terhadap penguasa. Ruang kesadaran bagi fenomenologi adalah sumber realitas, sementara fakta fisik, menjadi tidak ada jika tidak dimaknai oleh individu. Sehingga yang paling inti dalam konteks penelitian ini adalah, bagaimana pelaku pedagang asongan mengkonstruksi ketidakadilan di dalam pikiran dan tindakan mereka, tindakan dalam arti perlawanan yang mereka lakukan.

Lokasi penelitian ini dilakukan di stasiun dan kereta Merak-Rangkasbitung. Sementara pemilihan informan dilakukan secara purposive, yaitu para pedagang asongan. Data penelitian diperoleh dengan tiga cara yaitu: Pertama, observasi 
dengan melihat secara langsung kegiatan transaksi jual beli para pedagang asongan di stasiun dan kereta, cara menawarkan dagangannya kepada penumpang, cara bersembunyi dan menghindari petugas PT. KAI, dan kegiatan lainnya yang berkaitan dengan perlawanan seharihari yang dilakukan pedagang asongan. Kedua, wawancara secara mendalam (indepth interview) dengan menggunakan wawancara tak terstruktur terhadap informan yang telah terpilih. Wawancara dengan model ini akan memberi ruang yang lebih luas kepada informan untuk mengungkapkan apa yang mereka pikirkan (Fontana dan Fray, 2009). Ketiga, adalah data dokumentasi: buku, jurnal, serta referensi yang terkait dengan tema penelitian ini. Selanjutnya, data dianalisis mengikuti prosedur antara lain: pengumpulan data, penyajian data, reduksi data, dan verifikasi data.

\section{HASIL DAN PEMBAHASAN}

\section{Fenomena Pedagang Asongan di K.A Ekonomi Merak- Rangkasbitung}

Tidak bisa dipastikan sejak kapan pedagang asongan beroperasi di K.A lokal ekonomi Merak-Rangkasbitung. Namun sebagaimana diketahui, K.A lokal ini mulai beroperasi sejak 1990. Sebelumnya, hanya digunakan untuk mengangkut hasil-hasil pertanian. Diyakini bersamaan dengan beroperasinya K.A lokal ini, keberadaan pedagang asongan mulai ramai. Hal ini tidak bisa dihindari, selain karena keterbatasan lapangan pekerjaan di sektor formal, pendidikan yang belum sepenuhnya bisa diakses oleh semua warga, penggunaan K.A juga sangat diminati karena lebih murah dan sangat terjangkau bagi masyarakat kelas ekonomi lemah. Sampai dengan saat ini, harga tiket K.A Merak-Rangkasbitung masih sangat terjangkau, yakni Rp. 3.000, dengan jarak tempuh kurang-lebih 69 KM.

Pada awal-awal K.A ini beroperasi, rutenya adalah Merak-Angke, Jakarta Utara. K.A ekonomi Rangkas Jaya adalah satu-satunya yang beroperasi pada saat itu. Rute ini adalah yang terpanjang dan satu-satunya di Banten. Pedagang asongan memanfaatkan keramaian penumpang, pedagang dari Jakarta dan sekitarnya semakin memenuhi gerbonggerbong. Hal ini secara langsung maupun tidak menstimulasi warga sekitar stasiun, dalam tiap-tiap pemberhentian stasiunstasium menuju Merak sering ada saja pedagang asongan yang naik menjajakan macam-macam minuman, makanan, snack, dan lain sebagainya. Semakin ramainya pedagang lama kelamaan K.A ini nampak seperti "pasar" yang di penuhi oleh macam-macam pedagang, hari ke hari membuat kereta api semakin kumuh dan sesak, sehingga merasa hilang kenyamanan dan keamanan penumpang K.A ekonomi Rangkas Jaya.

Mengikuti banyaknya keluhan dari pelbagai pihak terhadap keberadaan pedagang asongan di K.A, sebagaimana fenomena ini juga berlaku secara nasional, maka PT. KAI mengeluarkan larangan berjualan di sekitar kereta api dan stasiun mengacu pada Undang- Undang No. 23 Tahun 2007 Pasal 35 ayat 2 serta UndangUndang No.73 tahun 2008 tentang Perkeretaapian. Halinimempertegasbahwa berjualan di kereta api dan stasiun adalah suatu tindakan yang tidak diperbolehkan dan dilarang. Untuk memperkuat aturan pelarangan ini, pada empat tahun setelahnya dikeluarkan kembali empat perundang-undangan dari pemerintah 
RI, Menteri Perhubungan, Menteri Dalam Negeri dan PT. KAI yang menjelaskan lebih spesifik tentang larangan berjualan, penumpang liar, dan penumpang yang merokok di dalam kereta.

Berdasarkan pelarangan itulah maka akses berjualan di dalam kereta dan stasiun bagi pedagang asongan ditutup. Siapapun pedagang asongan yang masih beroperasi dan diketahui petugas, mereka akan mendapatkan tindakan dari petugas. Sebagaimana juga perjalanan dari Merak-Rangkasbitung dan sebaliknya, mulai sepi. Tetapi permasalahan yang kompleks bagi warga ekonomi lemah, beberapa di anatara pedagang asongan sebenarnya tetap beroperasi dengan cara tidak menampakkan diri bahwa mereka berdagang. Mereka bekerja seperti “seolaholah", "seolah-olah" penumpang, "seolahseolah" warga biasa yang berlalu-lalang, dan bentuk-bentuk serupa yang lain.

Beberapa di antara pedagang asongan yang ada di K.A lokal ekonomi MerakRangkasbitung berasal dari Kecamatan Cikeusal dan beberapa tempat di sekitar stasiun perjalanan Merak-Rangkasbitung. Perjumpaan dengan mereka diketahui bahwa di antara yang banyak adalah perempuan yang telah menikah dan memiliki anak. Jenis barang yang dijual pedagang asongan sangat beragam, mulai dari lauk-pauk, minuman, tahu goreng, kerupuk, nasi putih, lemang, nasi ketan, lontong, buah-buahan, kacang rebus, makanan ringan, sampai telur asin. Penuturan yang seragam dari mereka bahwa, mereka hanya menjual saja, karena makanan tersebut diolah pemodal yang berada di lingkungan penjual. Dan sebagian dari mereka berjualan mengikuti jadwal kereta seperti keberangkatan kereta pertama dan terakhir, namun ada juga yang berjualan menetap di kereta tersebut dari gerbong ke gerbong hingga jadwal kereta telah habis. Pada hari-hari biasa pengguna kereta api lebih sedikit, sehingga pedagang asongan juga hanya sedikit saja, akan tetapi apabila pada hari Sabtu, Minggu atau hari-hari libur lainnya maka pedagang asongan sangat mudah ditemukan, karena jumlahnya yang banyak di sekitar stasiun.

\section{Kilas Balik Pemicu Perlawanan}

Bagi pedagang asongan yang biasa beroperasi di stasiun dan kereta, peraturan pelarangan berjualan di stasiun dan kereta sama dengan penutupan akses secara ekonomi dalam kehidupan mereka. Mereka kehilangan pekerjaan yang selama ini menopang banyak kebutuhan dalam keluarga mereka. Kondisi lain yang serupa adalah pergantian kereta Commuterline Rangkas-Tanah Abang sejak 1 April 2017, sama sekali tidak memberi peluang dan menutup akses bagi pedagang berjualan di dalamnya. Sebab kereta Commuterline memiliki kesan lebih efesien dan efektif, sehingga membuat jangkauan pedagang asongan lebih sempit.

Perilaku "bandel" pedagang asongan dapat dikatakan sebagai representasi keadaan orang-orang miskin lemah yang tidak memiliki alternatif solusi bagi perekonomian mereka di tengah kebutuhan yang semakin kompleks. Kebutuhan hidup sehari-hari yang terus menghimpit dan tidak bisa dihindari, akhirnya memaksa mereka untuk tetap berjualan di kereta dan stasiun walaupun memiliki resiko pengkerdilan diri mereka: diturunkan paksa meski membeli tiket, berusaha bohong, "adu mulut" sebagai orang kecil dengan petugas kereta, lari dari kejaran petugas stasiun, dan lain-lain. 
Namun apabila diuraikan lebih spesifik pemicu perlawanan pedagang asongan di kereta dan stasiun kereta Merak-Rangkasbitung, maka dapat jelaskan sebagai berikut:

\section{a) Tuntutan Ekonomi}

Diungkapkan dan berdasarkan keberadaan mereka yang sesungguhnya, bahwa hampir semua pedagang asongan yang nekat berjualan di stasiun dan kereta Merak-Rangkasbitung adalah untuk memenuhi kebutuhan hidup keluarganya. Stasiun dan kereta adalah tempat yang paling strategis bagi mereka berjualan kareana kedua tempat tersebut tidak akan sepi dan akan selalu ramai setiap harinya. Stasiun dan kereta khususnya kereta ekonomi merupakan tempat dimana orang-orang akan susah mencari makanan dan minuman, maka dari itu mereka (pedagang asongan) memanfaatkan situasi tersebut.

\section{b) Penghasilan Utama}

Sudah berusaha berjualan di tempat lain. Namun setelah mereka mencoba sepertidipasar Rangkasbitungdan tempat lainnya mereka lebih susah mendapat pembeli karena lebih banyaknya pesaing dan pedagang-pedagang lain yang lebih dulu dari pada mereka. Hal itu berarti mereka juga mengganggu mereka yang telah lama membuka usaha di tempat tersebut. Dengan alasan seperti itu mereka memilih untuk kembali berjualan di stasiun dan kereta walaupun harus menanggung resiko "dilempar" petugas, dengan kemampuan yang hanya bisa menjadi pedagang asongan mereka hanya bisa bergantung pada strategi-strategi yang digunakannya saat berjualan di stasiun dan kereta, hal tersebut menunjukan bahwa area stasiun dan kereta merupakan tempat yang paling menguntungkan mereka dibandingkan dengan tempat lain atau dengan kata lain kedua tempat tersebut adalah tempat penghasilan utama mereka.

\section{c) Larangan dan Outlet Makanan di Stasiun}

Pada tahun 2007 pemerintah mengeluarkan peraturan UndangUndang No. 23 Tahun 2007 tentang Perkeretaapian Pasal 35 ayat 2 yang didalamnya melarang pedagang asongan berjualan di area stasiun dan kereta. Larangan ini membuat mereka samasekali tidak diberikan peluang di area yang selama ini telah memberikan penghidupan. Sementara di lain pihak, di dalam kereta dan stasiun yang semula diisi oleh makanan produk petani dan orang-orang kalangan ekonomi lemah, saat ini justru diganti dengan makanan yang elit dan sangat mahal, misalnya Roti'O dan sejenisnya. Demikian pula di dalam kereta, makanan dikelola oleh PT KAI dan dijual di luar jangkauan pikiran orang-orang biasa, dalam artian mahalnya "gak ketulungan". PT. KAI memberi peluang luas bagi outlet terkenal selama ini seperti minimarket, kopi, restoran siap saji dan lain sebagainya.

\section{Seni Melawan}

Dimana ada kekuasaan, di sana ada perlawanan. Suatu ungkapan yang dapat mewakilifenomenaperlawananpedagang asongan di stasiun dan kereta MerakRangkasbitung. Istilah tersebut sebagai kata kunci untuk menggambarkan bahwa ada relasi inheren antara kekuasaan dan perlawanan. Seperti keping mata 
uang. Mendefinisikan kekuasaan tanpa melibatkan pertentangannya, maka definisi itu seperti tercerabut dari makna otentiknya. Orang melawan karena merasa dirinya dikuasai, kebebasannya diberangus, haknya diambil, dan lainlain. Bahkan menurut Haryatmoko (2010), menyatunya kekuasaan dan perlawanan dapat ditemui dijalanan. Orang mencoretcoret tembok yang di situ ada larangan "dilarang mencoret-coret tembok". Artinya, larangan mencoret tersebut adalah bentuk kekuasaan, karenanya ada perlawanan dengan mencoretnya.

Bagi pedagang asongan, berjualan di stasiun yang diketahui dengan baik ada larangan; diperingatkan lewat loadspeaker dan tulisan yang terpampang di tiap-tiap stasiun dan kereta, hal ini adalah bentuk yang konkret dari perlawanan terhadap kekuasaan yang muncul karena ada aturan itu sendiri. Sebagaimana yang dikenal oleh masyarakatbanyak,untukmengungkapkan kekesalan terhadap kekuasaan, Rohma (30) dengan sinis mengatakan: "aturan dibuat untuk dilanggar!". Bagi Rohma dan para pedagang asongan lainnya, hampir seluruh pengalaman dalam hidupnya sampai kini, adalah pengalaman menjadi orang yang diatur. Sebagai orang yang selalu menjadi objek aturan, alih-alih menguntungkan, yang dirasakan adalah menjadi orang yang selalu salah di mata kekuasaan, selalu mengganggu ketertiban, selalu dicurigai, dan pelbagai pelabelan yang mendiskreditkan kemanusiaan mereka. Orang-orang tidak berpendidikan, orang bodoh dalam persepsi pedagang asongan.

Suatu kebijakan tertentu dengan mekanisme apapun, seringkali ada bagian-bagian atau kelompok-kelompok masyarakat yang menjadi objek sasaran merasa dirugikan. Angkuhnya kekuasaan adalah, ketika diketahui ada yang dirugikan dari kebijakannya tetapi tidak memberi alternatif solusi bagi mereka. Kondisi ini dapat dibilang sebagai bentukbentuk diskriminasi terhadap orangorang yang dianggap musuh kekuasaan; dalam arti yang menjadi objek aturan sering dimaknai sebagai "yang harus dihilangkan", karena itu, secara tersirat ia dianggap musuh kekuasaan. Sebagaimana para pedagang asongan. Ia harus menghadapi penertiban, karena mereka semua yang menciptakan kondisi stasiun dan kereta berantakan. Maka berhadapan dengan Polisi Kereta Api (POLKA) maupun Satuan Pengaman (Satpam) yang bertugas untuk mengamankan dan menertibkan lingkungan sekitar stasiun adalah fenomena sehari-sehari. Justru dalam persepektif yang berkembang bagi orang-orang yang dikorbankan oleh kebijakan pemerintah seperti yang dialami Rohma (30) tidak ada yang terbesit kecuali membangkang. Karena sebagaimana yang ada dalam pikiran-pikiran mereka: "jika tidak melawan, kami tidak makan!"

Disadari oleh Urip (35) bahwa melawan dengan tetap berjualan secara terbuka berarti mereka bukan hanya melawan aparat, tetapi harus melawan stigmatisasi oleh masyarakat luas dalam arti penumpang kereta. Karena pengalamannya selama menjadi pedagang asongan, seringkali secara tidak langsung orang mempersepsikan ia bukan hanya sebagai orang tidak taat aturan, tetapi juga dianggap sumber dari segala kesemrautan dalam stasiun dan kereta. Karena sebagaimana fenomena sebelumnya dalam kereta dan stasiun, bukan hanya pedagang asongan yang mencari penghidupan, tetapi juga pengamen bahkan ada pula 
yang mencopet misalnya. Stigmatisasi itu adalah salah satu yang harus dilawan pedagang asongan. Meskipun ada juga penumpang yang bersimpati kepada mereka lantaran makanan maupun minuman yang disediakan pihak PT. KAI di luar batas kemampuan penumpang untuk membeli, karena begitu mahal. Sehingga kadangkala, ada penumpang yang menginginkan pedagang asongan yang menjual makanan yang ramah terhadap kantong mereka.

Kebijakan yang tidak memihak tersebut, sesungguhnya diketahui oleh sebagian besar pedagang asongan. Namun bagi mereka tidak ada jalan lain kecuali tetap berjualan apapun caranya. Dengan demikian, pengalaman beberapa di antara mereka memunculkan beberapa strategi yang sifatnya individual agar tetap bisa berjualan Beberapa macam bentuk-bentuk perlawanan pedagang asongan yang bersifat individual, yaitu:

\section{a) Pura-Pura Tidak Tahu dan Apatis Terhadap Hukum}

Pada dasarnya bentuk-bentuk perlawananyang dilakukan oleh pedagang asongan merupakan ekspresi spontan orang-orang kecil terhadap dominasi kekuasaan. Seni berkilah dari keadaan yang menurutnya mengerangkeng mereka. Marni (32) bertutur berdasarkan beberapa pengalamannya main "petakumpet" dengan aparat kereta api. Pada mulanya ia berpura-pura tidak mengerti dengan aturan yang baru diberlakukan oleh pemerintah. Meskipun telah ada sosialisasi sebelumnya, ia tetap berjualan. Namun tetap waspada dengan petugas, berusaha agar tidak diketahui, apabila terpaksa harus berhadapan dengan petugas, ia mengungkapkan bahwa ia tidak mengerti kalau ada peraturan pelarangan berjualan di kereta. Jika berhasil melakukan lobi, maka ia dapat diampuni, artinya tidak diturunkan paksa distasiun terdekat, namun apabila berhadapan dengan petugas yang tidak bisa dilobi ia terpaksa harus rela diturunkan paksa. Sikap membangkang ini adalah bentuk sinis dan apatis terhadap hukum, pura-pura tidak tahu, bernegosiasi dengan aparatus adalah fenomena yang khas sebagai senjata bagi orang-orang lemah seperti yang sering diaalami oleh pedagang asongan.

Suatu ketika, Marni (32) untuk kedua kalinya tertangkap oleh petugas. Kali ini ia terdesak dan tidak memiliki alasan lain yang dapat diterima oleh petugas. Ia diturunkan paksa tetapi bukan itu yang membuatnya jengkel terhadap petugas, melainkan karena dagangannya dirampas dan ia dipaksa membayar denda 200 ribu sebagai ganti atas pelangaran yang ia lakukan. Selain harus kehilangan uang 200 ribu, hal lainnya ia berarti ia harus mengganti barang dagangan tersebut kepada penyuplai. Apa yang terjadi pada saat itu bukan hanya dirasakan oleh dirinya, tetapi oleh sebagian temantemannya, dirampas dan diturunkan. Dirasa dirinya tidak diperlakukan seperti manusia pada umumnya, sehingga menimbulkan antipati bukan hanya pada hukum tetapi pada perlakukan petugas yang menghancurkan kemanusiaannya.

Diturunkan paksa, dirampas barang dagangannya, dan membayar denda, tidak membuat mereka berhenti berjualan. Sebab, selama bertahun-tahun mereka menggantungkan hidupnya dari gerbong ke gerbong, dari stasiun ke stasiun berikutnya, telah lama mereka beradaptasi dengan kondisi seperti ini. Di beberapa 
tempat selain stasiun kereta, bagi mereka berjualan di tempat lain, artinya mereka harus berhadapan dengan orang-orang yang telah lama berjualan di tempat lain. artinya masalahnya mungkin akan lebih kompleks dari sekedar menghadapi petugas. Karena tempat-tempat yang mereka tahu sudah dikuasai oleh orangorang yang sama dengan dirinya. Maka pilihan di antara pilihan di tempat yang sama, di kereta dan stasiun, adalah dengan berpura-pura tidak tahu peraturan, kondisi yang sebenarnya dalam diri mereka adalah tidak mau tahu tentang produk hukum yang menjerat mereka.

\section{b) Menyamar Menjadi Penumpang}

Karsih, adalah pedagang asongan yang menggunakan strategi penyamaran. Bagi perempuan 37 tahun ini, berjualan secara terbuka di tengah padatnya petugas melakukan razia, itu resikonya lebih cepat terditeksi seperti yang dialami oleh teman-temanya. Disadari oleh Karsih strateginya ini jika diketahui oleh petugas mungkin akan lebih menyedihkan dari pengalaman teman-temannya yang lain. Ia menaruh barang dagangannya di tas gendong, meskipun muatannya tidak banyak sebagaimana biasanya, namun tas lebih aman menyerupai penumpang lain. Menjadi penumpang sambil berjualan, sudah ia pertimbangkan. Salah satu alasan mengapa berani berjualan seperti ini karena membeli tiket RangkasbitungMerak masih tejangkau Rp 3.000. Selama lebih dari satu bulan, penyamarannya ini dapat dibilang berhasil, bahkan ia bukan hanya berjualan makanan, tetapi kadang juga menjual barang lainnya, seperti mainan anak-anak, dan segala jenis barang-barang yang terjangkau dan tidak mengeluarkan modal besar.
Karsih berpindah-pindah tempat duduk untuk menawarkan dagangannya, karenakeretaRangkasbitung-Merakadalah perjalanan lokal, dimana di dalam tiket tidak tertera nomor kursi bagi penumpang. Artinya penumpang bebas duduk di mana saja selama tempat duduk itu kosong. Baginya, selama penyamarannya ia mendapatkan jualannya berjalan dengan baik. Dan kadang mengambil barang ke penyuplai dalam sehari hingga dua sampai tiga kali. Sampai suatu ketika, petugas mulai mencurigai karena seringnya melihat ada di dalam kereta. Diceritakan bahwa ia diintrogasi dan diambil tasnya, dan diketahui ada banyak barang dagangan. Dan benar, selain dirampas, didenda sebanyak uang yang biasa diderita temantemannya yang lain, ia juga mendapat menyiksaan secara fisik, ia dihukum dengan berjemur di sekitar stasiun sambil diberikan sebuah papan nama dan alasan mengapa mereka tertangkap. Baginya, ia diperlakukan layaknya seorang pencuri atau pencopet yang beraksi di kereta api. Dipermalukan, dan di caci maki. Ia menggerutu mengingat kejadian itu: "Ini bukan salah satu solusi menghilangkan pedagang asongan untuk menjajakan dagangannya, karena sampai sekarang pun masih ada saja pedagang asongan yang berjualan di kereta walaupun sebelumnya ia pernah tertangkap dan mendapatkan hukuman. Dan kondisi ini, selama masih ada orang-orang miskin seperti saya, maka tidak akan pernah bisa dihilangkan".

\section{c) Aksi Negosiasi (Sebenarnya Seolah-olah)}

Strategi perlawanan ini adalah melakukan aksi negoisasi, bagaimana pedagang asongan dengan petugas kereta api sama-sama mencari jalan keluar 
yang baik, dan tidak merugikan kedua belah pihak serta tidak mengganggu kenyamanan penumpang lain. Negoisasi ini biasanya membagi area pedagang asongan untuk melakukan transaksi, jadi mereka tidak harus berkeliling dari satu gerbong ke gerbong yang lain. Ia diberi peluang dan toleransi oleh petugas kereta api untuk berjualan di gerbong awal dan gerbong akhir kereta saja, tidak boleh melakukan transaksi di area yang tidak diperbolehkan. Namun, perlawanan dari bentuk ini bagaimana pedagang asongan tetap berkeliling dan menyerupai penumpang sembari ia berpindah tempat, dengan begitu mereka tidak perlu khawatir akan adanya petugas yang mengelilingi, walaupun tidak jarang pula yang di turunkan karena melanggar kesepakatan awal dengan petugas kereta api. Selain adanya pembagian tempat yang diperbolehkan dan tidak diperbolehkan, berjualan ada juga negosiasi bagaimana mekanisme berjualan, Maman (29) menuturkan "Kata pak petugasnya, kalau saya lagi jualan pas engga ada bapaknya, engga apa-apa. Tapi kalau saya lagi jualan, terus ada bapaknya baru saya kena hukuman."

Ada beberapa petugas yang mungkin ikut merasakan seperti yang dirasakan oleh para pedagang asongan. Rasa iba tersebut dapat terlihat dari bagaimana mereka memberi kesempatan kepada pedagang asongan untuk berjualan seperti biasa dengan kesepakatankesepakatan yang telah di lakukan padanya. Dalam artian kesepakatan secara personal dengan beberapa petugas, sehingga beberapa pedagang asongan mungkin tahu kapan petugas A atau B yang piket pada hari tertentu. Maka dapat dikatakan bahwa ada sebagian yang peduli dengan nasib pedagang asongan, maka mereka mengurungkan niatnya untuk menurunkan dari kereta api dan melanjutkan perjalanannya hingga ke stasiun akhir. Namun bagaimanapun ibanya, ketika diketahui ada pelanggaran yang dilakukan oleh pedagang asongan tetap tidak diperbolehkan berjualan, artinya dia tetap diturunkan.

\section{d) Tidak Jera (Kami Melawan Dengan Berjualan)}

Setelah seluruh bentuk perlawanan dari pedagang asongan dan peringatan serta sanksi yang diberikan petugas kereta api kepada mereka, pada akhirnya pedagang asongan pun akan melakukan praktik-praktik diatas, selama kondisi tidak ada alternatif solusi bagi mereka. Perlawanan secara sembunyi-sembunyi yang dilakukan oleh pedagang asongan KA lokal ekonomi Merak-Rangkasbitung dikarenakan adanya subsistensi yang terus menerus memaksa mereka harus hidup secara minimal, banyak saran yang diberikan oleh para petugas kereta api untuk segera membuka lapaknya di daerah stasiun, namun hal itu tidak dapat dijalankan karena harga sewa yang mencekik, pajak tempat, modal yang lebih besar dan kalah saing. Para pedagang asongan mengetahui resiko-resiko yang akan terjadi apabila mereka terus menerus melawan secara bersembunyi namun itu lebih efektif daripada mereka harus melakukan demonstrasi untuk menuntut hak yang lebih layak bagi mereka. Karena mereka mengetahui hasil akhir tetaplah tidak menguntungkan bagi mereka, yang hanya mendapatkan caci maki dari masyarakat dan petugas kereta api. Dan secara politis, mereka tidak memiliki dukungan untuk menyuarakan hak- 
hak mereka, selain diri mereka sendiri. Perlawanan tersembunyi sesungguhnya adalah bentuk kenekatan mereka. Beberapa yang mendasari mereka adalah pendapatan minim apabila mereka hanya menggelar barang dagangannya saja di luar stasiun, dan harus saling "sikut" dengan sesama pedagang lainya yang telah lama menempati kawasan tersebut. maka, dengan segala kepahitan yang akan mereka tanggung, tidak cara lain bagi mereka, kecuali melawan dengan berjualan.

\section{KESIMPULAN}

Perlawanan tersembunyi, diam-diam, bisa disebut juga terselubung, merupakan ciri khas perlawanan orang-orang lemah oleh suatu situasi sosial yang dirasakan mengeksploitasi dirinya. Bagi mereka, orang-orang lemah atau yang dilemahkan, senjata satu-satunya sebagaimana dikatakan oleh Scott (2000) pura-pura tidak tahu, artinya tidak mau tahu, tidak berusaha mengorganisir diri mereka, karena selain mereka tidak memiliki pemahaman yang cukup tentang bagaimana melawan secara kolektif, mereka juga tidak memiliki bargaining position secara politik. Sehingga fenomena perlawanan tidak terlihat sebagai perlawanan yang sering tampak seperti gerakan sosial yang masif, namun sesungguhnya efektif memaksa kekuasaan tidak bekerja secara maskimal. Perlawanan sehari-hari pedagang asongan menyasar bagian-bagian terkecil dari organisme kekuasaan, ia tidak sanggup mematikan kekuasaan seperti kaum revolusioner, tetapi mengerogoti pelan-pelan.

Kekuasaan tidak bisa bekerja secara maksimal melalui regulasi yang mereka buat, ketika ada sejumlah kecil objek dari peraturan menegasikan dan tidak taat.
Pembangkangan adalah satu wujud yang sering disebut oleh kalangan positivis sebagai patologi sosial. Tetapi pada konteks perlawanan sehari hal ini adalah bentukperlawanan yang sesungguhnya ampuh untuk membuat peraturan lumpuh pelan-pelan. Pedagang asongan melawan dengan senjata pura-pura tidak tahu ada peraturan, menyamar sebagai penumpang sambil berjualan, bernegosiasi tentang perturan untuk tujuan melanggarnya kembali, melawan pelarangan berjualan dengan berjualan. Inilah ciri khas perlawanan sehari-hari orang lemah dan tidak memiliki kekuatan baik secara ekonomi, sosial dan politik.

\section{DAFTAR PUSTAKA}

Bakhtiar, Yudis Citra. 2015. Bentuk Perlawanan Tersembunyi Pedagang Kaki Lima di Alun-alun Jember. Skripsi. Universitas Jember.

Fringka, Yulisa. 2016. Resistensi Berbasis Adat: Perlawanan Masyarakat Nagari III Koto, Tanah Datar, Sumatera Barat, Terhadap Rencana Tambang Bukit Batubasi. MASYARAKAT: Jurnal Sosiologi 21(2):205-231.

Karnaji. 2005. Kalangan Marjinal di Perkotaan Studi Perlawanan Ex. Pedagang Kaki Lima di Taman Surya Surabaya. Jurnal Unair.

Malik, Abdul, dan Agus Prasetya. 2014. Konflik Pedagang Asongan Dengan PT. Kereta Api Madiun: Studi Perlawanan Pedagang Asongan Dengan PT. Kereta Api Madiun. Universitas Terbuka.

Siscawati, Mia. 2014. Masyarakat Adat dan Perebutan Penguasaan Hutan. Wacana Nomor. 33 Tahun XVI. 3-12.

Azuma, Yoshifumi. 2001. Abang Beca: Sekejam-Kejamnya Ibu Tiri Masih Kejam Ibukota. Jakarta: CV. Effata.

Fontana, Andrea; James Frey H. 2009. Wawancara Seni Ilmu Pengetahuan dalam Denzin, Norman K; Lincoln 
Yvonna S., Hand Book of Qualitative Research. Yogyakarta: Pustaka Pelajar.

Haryatmoko. 2010. Dominasi Penuh Muslihat: Akar Kekerasan dan Diskriminasi. Jakarta: Gramedia.

Jahyo, J. Noert. 2005. Dari Ladang Sampai Kabinet: Menggugat Nasib Petani. Jakarta: Buku Kompas.

Mills, Wright C. 1956. The Power Elite. Oxford University Press.

Muhadjir, Noeng. 2000. Metodologi Penelitian Kualitatif, Edisi Keempat. Yogyakarta: Rake Sarasin.

Neuman, W. Lawrence. 2013. Metodelogi Penelitian Sosial: Pendekatan Kualitatif dan Kuantitatif. Jakarta: Indeks.

Scott, James. 1993. Perlawanan Kaum Tani. Jakarta: Yayasan Obor Indonesia.

Jakarta: LPP3ES.

1994. Moral Ekonomi Petani. 2000. Senjatanya Orang-Orang Yang Kalah. Jakarta: Yayasan Obor Indonesia.

Instruksi Direksi PT. KAI No. 26/ LL.006/KA-2012 tentang Penerbitan Pedagang Asongan, Penumpang Liar dan Larangan Penumpang Merokok di atas KA.
Peraturan Menteri Dalam Negeri RI No. 41 Tahun 2012 pasal 32 dan 38.

Peraturan Menteri Perhubungan No. 9 Tahun 2011 tentang Standar Pelayanan Minimum untuk angkutan orang dengan kereta api.

Peraturan Pemerintah RI No. 72 Tahun 2009 tentang Lalu Lintas dan Angkutan kereta api pasal 124.

Undang-Undang No.73 tahun 2008 tentang Perkeretaapian;

Undang-Undang No. 23 Tahun 2007 tentang Perkeretaapian Pasal 35 ayat 2;

www.keretaapi.id

www.kompasiana.com/sujadi/ menaklukan-pedagang-asongan-diatas-ka 54f0864ba3331176038b5262

www.wikiwand.com/id/stasiun rangkasbitung/

www.bantenhits.com/2016/01/05/wklkepala-stasiun-rangkasbitungdiduga-aniaya-pedagang-asongan/

ht t p://m.tribunnews.com $/$ metropolitan $/ 2017 / 03 / 30 / \mathrm{ka}-$ rangkasbitung-tangh-abang-siapberoperasi-1-april-2017 